О. М. Хвисюк, В. Г. Марченко, О. А. Цодікова, А. В. Яловчук, О. О. Рожнов, Н. М. Гріднєва, С. С. Бринцова, І. Г. Лапіна Харківська медична академія післядипломної освіти

\title{
ДИДАКТИЧНІ АСПЕКТИ ОПТИМІЗАЦІЇ БЕЗПЕРЕРВНОЇ МЕДИЧНОЇ ОСВІТИ ДІЛЬНИЧНИХ ПЕДІАТРІВ
}

\author{
O. M. Khvysiuk, V. H. Marchenko, O. A. Tsodikova, A. V. Yalovchuk, O. O. Rozhnov, \\ N. M. Hridnieva, S. S. Bryntsova, I. H. Lapina \\ Kharkiv Medical Academy of Postgraduate Education \\ DIDACTIC ASPECTS OF DISTRICT PEDIATRICIANS CONTINUOUS \\ MEDICAL EDUCATION OPTIMIZATION
}

\begin{abstract}
Мета роботи - поділитись власним досвідом та думками про вдосконалення методів безперервної медичної освіти в умовах реформування охорони здоров'я.

Основна частина. У статті висвітлено проблеми безперервної медичної освіти дільничних педіатрів. Представлено власний погляд на оптимізацію навчального процесу, що полягає в підвищенні змістовних аспектів підготовки лікаря, застосуванні ефективних педагогічних прийомів і методик, а також широкому впровадженні новітніх інформаційних технологій. Це дозволяє лікарю одержати освітні послуги прямо на робочому місці чи вдома, підвищити ступінь індивідуалізації і диференціації навчання, покращити мотиваційну активність, окрім цього, знизити фінансову залежність, що є не менш важливим у наш час.

В умовах реформування охорони здоров'я бажано, щоб цикли тематичного удосконалення були короткотривалими: 5,10 , 14 днів, а їх кількість - не обмежувалася протягом року.

Тематика циклів тематичного удосконалення сучасних дільничних педіатрів обов’язково має бути спрямована на профілактику, збереження й зміцнення здоров'я дітей і орієнтована на доказову медицину. Такий підхід сприятиме якісній підготовці висококваліфікованого спеціаліста, формуванню його професійної компетенції на всіх етапах безперервного професійного розвитку.

Використовуючи сучасне комп’ютерне обладнання та технічні засоби навчання (достатня кількість комп’ютерів, інтерактивна дошка, симулятори, Smart-система для інтерактивного тестування), впровадження передових педагогічних прийомів, методів і технологій сприяє формуванню необхідного рівня знань педіатрів.

На циклах (у тому числі й на виїзних) проводяться бінарні лекції, що підвищує ефективність засвоєння матеріалу заняття та сприяє активності слухачів, використовуються елементи дистанційного навчання на базі платформи Moodle XMAПО (moodle. med.edu.ua) з додатковими консультаціями викладачів по Skype у Центрі дистанційної освіти академії.

У перспективі, в умовах конкурентного освітнього середовища відбудеться “вільний вибір закладу, форми навчання (курси, стажування, e-Learning)”. Дільничні педіатри будуть самі обирати й оцінювати роботу вищого медичного навчального закладу за якістю наданої їм навчальної послуги.

Висновки. Інформаційні технології в медичній освіті оптимізують та підвищують ефективність безперервного професійного розвитку сучасного лікаря-педіатра.

Впровадження нових сучасних методів у медичну освіту дільничних лікарів сприяє формуванню нового мислення, підвищенню зацікавленості та задоволеності навчальним процесом.
\end{abstract}

Ключові слова: безперервна медична освіта; інформаційні технології; дільничні педіатри.

The aim of the study is to share the experience and views on improving methods of continuous medical education under health care reform.

The main body. The article deals with the problem of district pediatricians continuous education and to set out own reading of educational process optimization. The educational process optimization is specified by valuable intentional aspects of doctor training, application of effective pedagogical methods, wide implementation of informational technologies. It allows doctor to use education services directly at working place or at home, to improve level of individualization and differentiation of training, to improve motivation, and also to decrease financial dependence that is just as important nowadays. Under heltcare reform it is desirable, that cycles of advanced thematic training are short-time: 5, 10, 14 days, and their amount are not restricted during the year.

Subjects of the advanced thematic training of district pediatricians must be aimed at children health preventive, maintenance and strengthening and oriented to evidence-based medicine. This kind of approach is going to promote high-quality training of highly experienced specialists, forming his professional competency at all the stages of continuous professional development.

Using modern computer equipment and teaching aids (right amount of computers, interactive boards, simulators, Smart-system for interactive testing), the introduction of advanced teaching techniques, methods and technologies contributes the necessary level of knowledge of pediatricians.

During cycles (including on-site ones) binary lectures, which increase the effectiveness of learning material assimilation and promote students' activeness are held; the elements of distance learning platform based on Moodle KhMAPE (moodle.med.edu.ua) with additional review sessions on Skype at the Center of Distance Education of Academy are used.

(c) О. М. Хвисюк, В. Г. Марченко, О. А. Цодікова та ін. 
Looking forward, in conditions of concurrent education environment, it will be possible "to make free choice of educational establishment, education form (courses, internship, e-Learning)". District pediatricians will choose and estimate the work of medical educational organization by themselves corresponding to given education service.

Conclusions. Information technologies for medical education optimize and increase the effectiveness of continuous modern pediatrician professional development. The introduction of new advanced methods into district doctors' medical education promotes new thinking, increases interest and satisfaction with the educational process.

Key words: continuous medical education; informational technologies; district pediatricians.

Вступ. Упродовж десятиріч методологія педагогіки у післядипломному навчанні вітчизняних лікарів-педіатрів залишалася незмінною. Лікарі протягом навчального курсу підвищення кваліфікації прослуховували лекції, працювали на семінарських та практичних заняттях, спілкувалися з викладачами (дискусії, клінічні розбори тощо), проходили відповідне тестування (перевірка базового рівня знань, межове та заключне).

Сьогодні запорукою якісної підготовки висококваліфікованого спеціаліста медичної галузі, зокрема педіатра, є практико-орієнтоване навчання. Саме за рахунок виконання реальних практичних завдань, відпрацювань та закріплення практичних навичок, розвитку здібностей миттєво приймати рішення та бездоганно виконувати безліч маніпуляцій, у медика формуються професійні компетенції на всіх етапах безперервного професійного розвитку.

Мета роботи - поділитись власним досвідом та думками про вдосконалення методів безперервної медичної освіти в умовах реформування охорони здоров'я.

Основна частина. Проникнення у вищу медичну освіту ідей кібернетики примушує зовсім інакше подивитися на дидактичний процес вищої медичної школи, в якому прийоми математичного моделювання й інформаційні технології дозволяють значно оптимізувати функціонування та ефективність безперервного професійного розвитку сучасного лікаря [1].

У цьому сенсі є низка факторів, які також спонукають серйозно переглядати концептуальні проблеми післядипломного навчання сучасних лікарівпедіатрів. Так, сьогодення вже не дозволяє дільничному педіатру мати тривалі терміни навчання на курсах тематичного удосконалення, як це було раніш. Величезний об’єм роботи педіатра в умовах реформи галузі (зокрема пов’ язаний із збільшенням кількості документації), відповідальність по відношенню до своїх маленьких пацієнтів та їх батьків унеможливлюють відрив фахівця надовго від своєї дільниці, відділення або офісу. Бажано, щоб цикли тематичного удосконалення були короткотривалими: 5, 10, 14 днів, а їх кількість - не обмежувалася протягом року.
Дані обставини обгрунтовують й необхідність широкого використання в безперервній медичній освіті інформаційних технологій, впровадження яких здатне не тільки зменшити час перебування лікаря в аудиторії (лікар одержує освітні послуги у свого комп'ютера, прямо на робочому місці чи вдома), має забезпечити зворотний зв'язок між викладачем і слухачем; підвищити ступінь індивідуалізації і диференціації навчання, покращити мотиваційну активність фахівця [2].

Втім, інформаційну складову, що забезпечує змістовний аспект сучасної підготовки лікаря-педіатра, неможливо розглядати без таких складових, як: комп’ютерні засоби навчання, засоби управління освітнім процесом, які спрямовані на формування необхідного рівня знань, умінь і навичок.

Важливим питанням змістового аспекту підготовки сучасного дільничного педіатра слід вважати й тематику циклів тематичного удосконалення, які повинні бути спрямовані на профілактику, збереження й зміцнення здоров'я дітей. Основним вектором післядипломного навчання лікарів амбулаторно-поліклінічної служби повинно бути одержання нових знань, необхідних при організації диспансерного нагляду дитини, вакцинального процесу; вміння відпрацьовувати навички ефективного консультування батьків та дітей із питань підвищення мотивації на збереження власного здоров'я, профілактики захворювань, дотримання гігієнічних правил, у тому числі психогігієни, культури взаємин у повсякденному житті, фізичної активності, загартовування організму, повноцінного харчування, запобігання шкідливим звичкам.

Останнім часом тематика циклів орієнтована й на доказову медицину, що зможе допомогти лікарю ефективно діяти в конкретних клінічних ситуаціях, уникаючи неефективних та помилкових втручань.

Як свідчить власний досвід, зазвичай й самі слухачі досить часто пропонують науковцям розробку нових додаткових тематичних циклів, що викликано необхідністю розбору складних клінічних випадків, безліччю нерозв'язаних питань клінічної педіатрії, одноманітністю тематик на більшості педіатричних кафедр. 
Кафедра поліклінічної педіатрії, яка вже 30 років займається підготовкою лікарів первинного контакту, робить все можливе, щоб навчальні цикли були цікавими та сучасними 3 позицій новітніх технологій.

Ось декілька тематик, які найбільш популярні серед педіатрів та лікарів загальної практики - сімейної медицини в різних регіонах України: “Поліклінічні аспекти організації профілактичних щеплень та протоколи медичного догляду за дітьми раннього віку”, “Диференціальна діагностика симптомів та синдромів у поліклінічній педіатрії” i “Медичні аспекти забезпечення оздоровлення та відпочинку дітей в умовах дитячих оздоровчих закладів” тощо.

Кафедра поліклінічної педіатрії ХМАПО добре технічно забезпечена для якісного освітнього процесу: в арсеналі є сучасне комп’ютерне обладнання та технічні засоби навчання (достатня кількість комп’ютерів, інтерактивна дошка, симулятори, Smart-система для інтерактивного тестування). Широко використовуються й передові педагогічні прийоми, методи і технології, спрямовані на формування необхідного рівня знань педіатрів [3]:

- на циклах (у тому числі й на виїзних) проводяться бінарні лекції, що підвищує ефективність засвоєння матеріалу заняття та сприяє активності слухачів (“Хронічний тонзиліт у дітей: міждисциплінарний підхід до лікування, реабілітації та диспансерного нагляду”, “Солідні пухлини у дітей раннього віку: міждисциплінарний підхід до діагностики, лікування та поліклінічного нагляду”, “Аномалії конституції” та ін.);

- використовуються елементи дистанційного навчання на базі платформи Moodle ХМАПО (moodle. med.edu.ua) 3 додатковими консультаціями викладачів по Skype у Центрі дистанційної освіти академії.

Зараз кафедра готує програми до дистанційних циклів виключно на платформі Moodle. Це дозволить не тільки збагатити наповнення програми

\section{Список літератури}

1. Інноваційні освітні технології в реалізації програм безперервного професійного розвитку лікарів / О. М. Хвисюк, В. Г. Марченко, В. В. Жеребкін [та ін.] // Медична освіта. - 2014. - № 4. - С. 124-127. doi: 10.11603/me.v0i2.3651.

2. Обгрунтування впровадження симуляційних технологій на післядипломному етапі ступінчастої системи практично-орієнтованого навчання лікарів загальної практики - сімейної медицини / О.М.Хвисюк, В. Г. Марченко, О. А. Цодікова, О. М. Корж // Проблеми безпе- інформаційним матеріалом (електронні книги, презентації, інше) та тестами, але й надасть можливість для спілкування слухачів (форуми для спілкування, обговорення варіантів рішення практичних занять, за що нараховуються додаткові бали), буде сприяти збільшенню кількості відвідувань дистанційного курсу та підвищенню зацікавленості й задоволеності лікарів до навчання.

У своєму виступі "Реформа медичної освіти: рішучі зміни у нерішучому середовищі” заступник міністра МОЗ України О. Лінчевський наголосив, що “основним аспектом оцінки роботи вищих медичних навчальних закладів мають бути не кількісні показники, а якість підготовки медичних кадрів” [4].

Висновки. 1. Інформаційні технології дозволяють значно оптимізувати функціонування та ефективність безперервного професійного розвитку сучасного лікаря-педіатра - зменшується час перебування лікаря в аудиторії, підвищується ступінь індивідуалізації і диференціації навчання, покращується мотиваційна активність фахівця.

2. Тематика циклів тематичного удосконалення сучасного дільничного педіатра має бути спрямована на профілактику, збереження й зміцнення здоров’я дітей, а також орієнтована на доказову медицину.

3. Широке використання передових педагогічних прийомів, методів і технологій сприяє формуванню необхідного рівня знань педіатрів, а також підвищенню зацікавленості та задоволеності навчальним процесом.

I, можливо, у перспективі зовсім скоро, в умовах конкурентного освітнього середовища, де “гроші йдуть за слухачем (курсантом)” і відбудеться “вільний вибір закладу, форми навчання (курси, стажування, e-Learning)”. Дільничні педіатри будуть самі обирати й оцінювати роботу вищого медичного навчального закладу за якістю наданої їм навчальної послуги.

рервної медичної освіти та науки. - 2015. - № 3. - С. 6-9.

3. Роль “бінарної лекції” в розвитку професійної компетенції лікарів первинного контакту / О. М. Хвисюк, В. Г. Марченко, О. А. Цодікова [та ін.] // Проблеми безперервної медичної освіти та науки. - 2016. - № 3. - С. 6-9.

4. Лінчевський О. Парламентські слухання на тему “Медична освіта в Україні: погляд у майбутнє” / О. Лінчевський. - Режим доступу : https://www.slideshare.net/ MOZukr/ss-73506506). 


\section{References}

1. Hvysiuk, O.M., Marchenko, V.H., Zherebkin, V.V., Zhadan, I.A., Sobolieva, I.A., Bodnia, K.I., ... Kolomiichenko, N.O. (2014). Innovatsiini osvitni tekhnolohii $\mathrm{v}$ realizatsii prohram bezperervnoho profesiinoho rozvytku likariv [Innovative technologies within programs of doctors continuous professional development implementation]. Medychna osvita - Medical education, 4, 124-127 [in Ukrainian].

2. Hvysiuk, O.M., Marchenko, V.H., Tsodikova, O.A., \& Korzh, O.M. (2015). Obhruntuvannia vprovadzhennia symuliatsiinykh tekhnolohii na pisliadyplomnomu etapi stupinchastoi systemy praktychno-oriientovanoho navchannia likariv zahalnoi praktyky - simeinoi medytsyny [Justification for simulation technologies implementation at the postgraduate stage of staged system of family physicians practice oriented education]. Problemy bezperervnoi medychnoi osvity ta nauky - Problems of lifelong medical education and science, 3, 6-9 [in Ukrainian].

3. Hvysiuk, O.M., Marchenko, V.H., Tsodikova, O.A., Korzh, O.M., Bryntsova, S.S., Rozhnov, O.O., \& Lapina, I.H. (2016). Rol binarnoi lektsii v rozvytku profesiinoi kompetentsii likariv pervynnoho kontaktu [The role of binary lecture in the development of first contact physicians professional competence]. Problemy bezperervnoi medychnoi osvity ta nauky - Problems of lifelong medical education and science, 3, 6-9 [in Ukrainian].

4. Linchevskyi, O. (2017). Parlamentski sluhannia na temu: «Medychna osvita v Ukraini: pohliad u maibutne» [Parliament proceedings on a topic "Medical education in Ukraine: future outlook”]. Retrieved from https://www. slideshare.net/MOZukr/ss-73506506 [in Ukrainian].

Отримано 09.03.17

Електронна адреса для листування: rognov@ukr.net 